\title{
SOME ASSOCIATED RISK FACTORS WITH THE OCCURRENCE OF RIFT VALLEY FEVER IN ANIMALS AND MAN IN CERTAIN LOCALITIES OF NILE DELTA, EGYPT
}

\author{
A.M. BYOMI*; H.A. SAMAHA ${ }^{* *}$; S.A. ZIDAN* and G.A. HADAD* \\ *Department of Hygiene and Zoonoses, Faculty of Vet. Med., University of Sadat City \\ ** Department of Hygiene and Zoonoses, Faculty of Vet. Med., Alexandria University. \\ *Corresponding author. E-mail: shrifzidan@yahoo.com
}

\section{ABSTRACT}

Received at: $21 / 10 / 2014$

Rift Valley Fever (RVF) is acute viral mosquito-borne disease of Ruminants and man that can cause epizootics and associated human epidemics. This study was carried out for detection of RVFV IgG in animals and man and to investigate the occurrence of RVFV in mosquitoes. A total of 460 animal blood samples were

Accepted: 9/12/2014 collected from vaccinated and non vaccinated sheep (172), goats (48), cattle (164) and buffaloes (76) from different farms, flocks and abattoirs in Menoufia, Behera and Kafr El Sheikh Governorates. All samples were examined by indirect Enzyme Linked Immunosorbant Assay, the overall detection percentages of RVFV IgG antibodies were $14.9 \%$ in non-vaccinated animals and $19.2 \%$ in vaccinated animals, respectively and it was found that Kafr El sheikh had the higher percentage than the other two Governorates $(21.4 \%)$. Also sheep and goat represented the most principle host to RVF by a parentages of $21.4 \%$ and $18.7 \%$ respectively, especially on the age group > 3- 5 years by $(17.9 \%)$. Moreover, female animals had the higher percentage $(17.7 \%)$ than males $(8.6 \%)$. Furthermore this study proved that RVF play an important role in abortions especially in sheep and goats. In human, a total of 369 human blood samples collected from fever hospitals and clinical laboratories in the three Governorates. It was found that males contacted to animals such as sheepherders, farmers and butchers showed higher percentage $(12.9 \%)$ than females, especially in the age group 30-45 years by a percentage of $16.6 \%$. This results potentiate the role of animals in transmission of disease to man. Concerning mosquitoes, a total of 872 mosquitoes were collected by using CDC light trap and identified into 32 mosquito pool according to genus Culex, Aedes and Anopheles, culex constituted the higher percentages of $71.8 \%$. All mosquito samples did not give any band at the expected size 342 bp by RT- PCR. This negative result did not mean that the virus completely absent as might be present in a low level in the study area or might be present in other Governorates in Egypt.

Key words: RVF, ELISA, RT-PCR, Egypt

\section{INTRODUCTION}

Rift Valley Fever is an emerging zoonotic mosquito-borne viral disease associated with large outbreaks of severe disease throughout Sub-Saharan African countries and the Arabian Peninsula (Ikegami and Makino, 2011). RVF is disease of global importance with potentially severe consequences for human and animal health responsible for large explosive outbreaks of acute febrile disease in humans and livestock with significant mortality and economic impact (Bird et al., 2007). In animal, RVF results in significant economic losses due to abortions and high mortalities of newborn in livestock, (Bird et al., 2008). Human infection results in self-limiting febrile disease that in approximately $1-2 \%$ of patients progresses to more serious complications including hepatitis, encephalitis. retinitis and a hemorrhageic syndrome with high fatality (Bird et al., 2008). Epizootics of RVF are often occurs at irregular intervals when heavy rains flood natural depressions in the grasslands of Sub- Saharan Africa (Swaneopel and Coetzer, 1994). Flooding allow the hatching of the primary vector and reservoir, multiple species of mosquitoes known as Flood Water Aedes (Woods et al., 2002).

RVF can be demonstrated in Enzyme linked immunoassay (ELISA), Indirect immunofluorescence or Neuterlization tests. ELISA is a rapid, specific and useful tool to reveal infected animal in endemic areas or during an epizootic (Paweska et al., 2005). As 
well, the reverse transcriptase polymerase chain reaction (RT-PCR) could be of great interest for the rapid diagnosis and screening of new antiviral compounds, as it is sensitive, time saving and does not require manipulation of infectious material.

Due to the public health significance and economic importance of RVF. This work was applied to investigate the percentages of RVFV Immunoglobulin $\mathrm{G}$ antibodies among some animals (Sheep, Goats, Cattle and Buffaloes) and human population as well as the occurrence of RVFV in Some mosquitoes (Culex, Aedes and Anophles) by using Reverse - Transcriptase Polymerase Chain Reaction (RT-PCR) in three Egyptian Governorates.

\section{MATERIALS and METHODS}

The study was carried out during the period from April 2009 till March 2010 for investigation of RVF in some animals species and man and in Menoufia, Kafr-El shiekh and El- Behera governorates by Indirect Enzyme Linked Immunosorbent Assay (ELISA). The detection of RVF virus antigen in mosquito pools were also performed by Reverse Transcriptase Polymerase Chain Reaction (RT-PCR) to confirm the proposed role of mosquitoes in transmission between the disease hosts.

\section{Detection Frequency of RVFV IgG antibodies by using ELISA assay:}

A total of 460 blood samples were collected from sheep (172), goats (48), cattle (164) and buffaloes (76) for detection of RVF virus specific antibodies. These animals belonged to different animal farms, sheep flocks, private animals and some abattoirs at the three governorates. Each animal was identified according to species, age, sex, vaccination status, locality, time of sampling and presence or absence of previous history of abortion. Moreover, 369 human blood samples were collected from apparently healthy persons and febrile patients visiting Fever Hospitals, private clinics and laboratories in the three governorates. Those persons had previous history of contact with animals like animal owners, butchers, farmers, veterinarians, sheepherds as well as from non contact animal persons such as children, housewives and other individuals. Each sample was identified with full data regarding to name, age, sex, occupation, season, locality, health status, previous history of fever and contact with animals, carcasses and secretions from animals especially after abortions. The collected blood samples from animal and human were immediately transported to the laboratory. Blood samples were refrigerated and serum was obtained. All serum samples were stored at $-20^{\circ} \mathrm{C}$ until tested for RVFV antibodies by ELISA assay.
Detection of RVFV IgG antibodies in animal and human serum samples:

The detection of RVF IgG antibodies was performed according NAMRU-3 (1998) and Paweska et al. (2005).

\section{Detection of RVFV in collected mosquito pools using RT-PCR:}

RT-PCR was carried out on all mosquito pools in the central laboratory of virology, Department of virology, Faculty of veterinary medicine, Sadat City University.

\section{Collection of Mosquitoes samples:}

A total of 872 mosquitoes ( 32 mosquito groups) like Culex (23 pools), Aedes (7 pools) and Anopheles (2 pools)) were collected by CDC light trap from ElMenoufia, Behera and Kafr El-Sheikh governorates. Mosquitoes were nearly collected from the same places where animal blood samples were obtained according to Gad et al. (1995). The collected mosquitoes were identified into 32 pools (each pool contains 25-50 mosquitoes of one genus only) (Youssef, 2001; Maysa, 2006 and Youssef et al., 2008), labeled according to genus, then frozen immediately at $-70^{\circ} \mathrm{C}$ until examination.

\section{Extraction of RNA from mosquito pools:}

Homogenization of mosquito pools were performed according to Meegan et al. (1980). RNA was extracted from homogenized mosquitoes, Inactivated RVF vaccine and RVF virus ( $\mathrm{ZH}$ 501) (control positive) that was provided from RVF department, Veterinary Serum and Vaccine Research Institute, Abbassia, Cairo by using the kit (QIAamp viral RNA kit) (Qiagen, Hilden, Germany). The purified RNA pellets were preserved at $-70^{\circ} \mathrm{C}$ until used.

One Step RT-PCR for detection of RVFV (QIAGen, California, USA):

A single tube RT-PCR amplification was carried out using One Step Access RT-PCR system (Table 3) according to Salim et al. (2010).

\section{Primers selection:}

Selection of the primers was based on nucleotide sequence of the $M$ segment of Smithburn vaccine strain, and complete nucleotide sequences with Gene Bank accession number DQ 380193. The primers specific for amplification of RVFV M segment were designed based on multiple sequences alignment of 20 published conserved sequences of the genes using Bio Eidit software (Carlsbad, CA, USA). The RTPCR would produce a 342 bp PCR product, Primers included bases of 2163-2182of the positive sense strand of the $M$ RNA gene 5CTGTCTGGCACAGCATTGAT-3 in RV1, and the complementary strand included 2485-2504 bases 5CACATTGAAACACCCACACC-3 in RV2 according to Salim et al. (2010). 


\section{RESULTS}

Table 1: Detection of RVFV IgG antibodies among the examined animal serum samples by using ELISA test.

\begin{tabular}{lccc}
\hline & \multirow{2}{*}{$\begin{array}{c}\text { Total number of examined } \\
\text { serum samples by ELISA test }\end{array}$} & Seropositive samples & \\
\cline { 3 - 4 } & 172 & No of positive samples & \% \\
\hline Sheep & 48 & 37 & 21.5 \\
\hline Goats & 164 & 6 & 12.5 \\
\hline Cattle & 76 & 29 & 17.6 \\
\hline Buffaloes & 460 & 7 & 9.2 \\
\hline Total & & 79 & 17.2 \\
\hline
\end{tabular}

Table 2: Detection of RVFV IgG antibodies among the examined animal serum samples in relation to vaccine state, animal species and localities by using ELISA test.

\begin{tabular}{|c|c|c|c|c|c|c|c|c|c|c|c|c|c|c|c|}
\hline & \multicolumn{3}{|c|}{ Vaccinated } & \multicolumn{12}{|c|}{ Non vaccinated animals } \\
\hline & \multirow{2}{*}{$\begin{array}{l}\text { No } \\
\text { No }\end{array}$} & \multirow{2}{*}{$\begin{array}{l}\text { +ve } \\
+ \text { ve }\end{array}$} & \multirow{2}{*}{$\frac{\%}{\%}$} & \multicolumn{3}{|c|}{ El Menoufia } & \multicolumn{3}{|c|}{ El Behera } & \multicolumn{3}{|c|}{ Kafr El Sheikh } & \multicolumn{3}{|c|}{ Total } \\
\hline & & & & No & $+\mathrm{ve}$ & $\%$ & No & + ve & $\%$ & No & + ve & $\%$ & No & + ve & $\%$ \\
\hline Sheep & 102 & 22 & 21.5 & 28 & 3 & $(10.7)$ & 16 & 5 & $(31.2)$ & 26 & 7 & $(26.9)$ & 70 & 15 & $(21.4)$ \\
\hline Goats & 32 & 3 & 9.4 & 2 & 0 & $(0.0)$ & 8 & 1 & $(12.5)$ & 6 & 2 & $(33.3)$ & 16 & 3 & $(18.7)$ \\
\hline Cattle & 72 & 16 & 22.2 & 20 & 2 & (10) & 31 & 4 & $(12.9)$ & 41 & 7 & $(17.1)$ & 92 & 13 & $(13.9)$ \\
\hline Buffaloes & 33 & 5 & 15.2 & 19 & 1 & $(5.3)$ & 13 & 0 & $(0.0)$ & 11 & 1 & $(9.1)$ & 43 & 2 & (4.6) \\
\hline Total & 239 & 46 & 19.2 & 69 & 6 & (8.7) & 68 & 10 & (14.7) & 84 & 17 & $(21.4)$ & 221 & 33 & (14.9) \\
\hline
\end{tabular}

The overall detection percentages of RVFV IgG antibodies in sheep, goats, cattle and buffalo were $14.9 \%$ in non-vaccinated animals and $19.2 \%$ in vaccinated animals, respectively. RVFV IgG antibodies were detected among non vaccinated animals in the three governorates at a precentages of $21.4,18.7,13.9$ and $4.6 \%$ among sheep, goats, cattle and buffaloes, respectively.

Table 3: Detection of RVFV IgG antibodies among the examined non- vaccinated animal serum samples in relation to age, sex, season and history of abortion by using ELISA test.

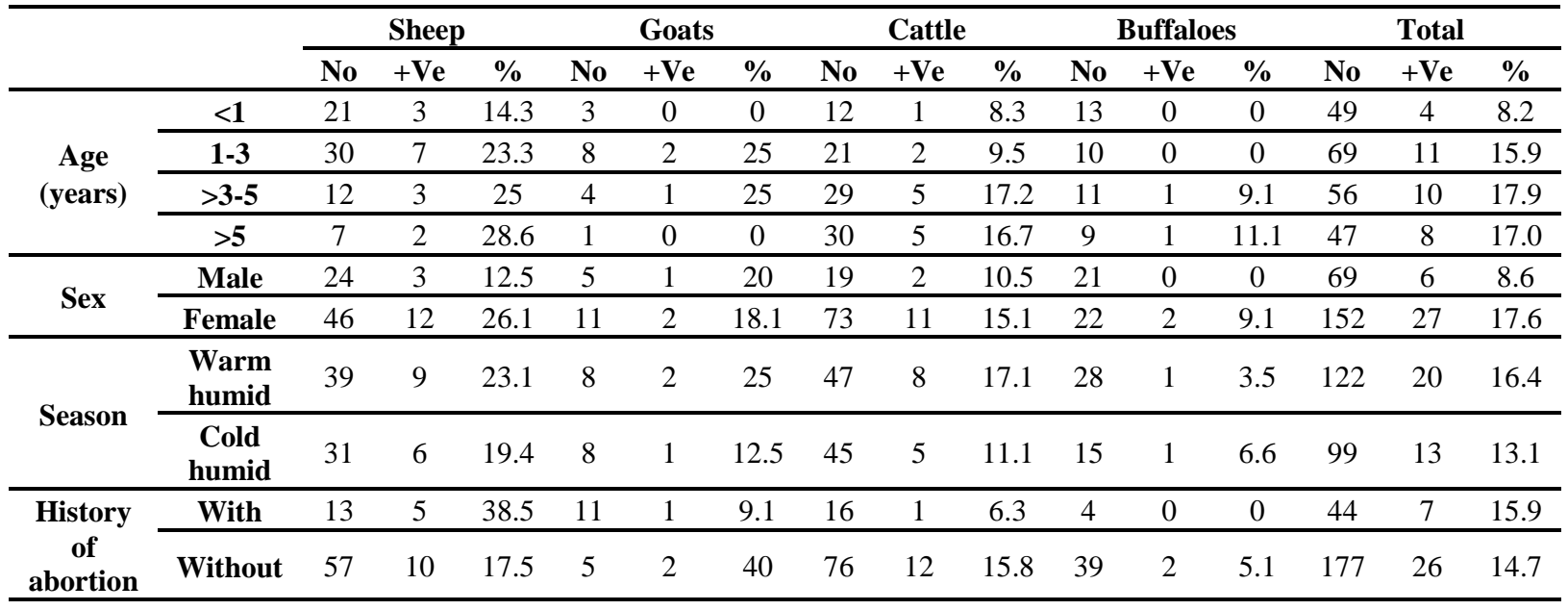

The detection percentages of RVFV IgG antibodies among sheep<1year; 1-3years; 3-5years old and >5years old were $14.2 ; 23.3 ; 25$ and $28.5 \%$, respectively. In goats, the detection percentages were $0 ; 25 ; 25 ;$ and $0 \%$, respectively among the examined age groups. The detection percentages among age groups of the examined 
cattle were $8.3 ; 9.5 ; 17.2$ and $16.6 \%$, respectively. In buffaloes, the detection percentages among the age groups were $0 ; 0 ; 9.1$ and $11.1 \%$, respectively.

Table 4: Detection of RVFV IgG antibodies among the examined human serum samples by using ELISA test.

\begin{tabular}{lccc}
\hline \multirow{2}{*}{ Localities } & $\begin{array}{c}\text { NO. of examined human serum } \\
\text { samples by ELISA test }\end{array}$ & \multicolumn{2}{c}{ Sero - positive } \\
\cline { 2 - 4 } El-Menoufia & 129 & No. of +ve & $\%$ \\
\hline El-Behera & 125 & 7 & 5.4 \\
\hline Kafr El- sheikh & 115 & 22 & 13.1 \\
\hline Total & 369 & 42 & 11.3 \\
\hline
\end{tabular}

The detection percentages of RVFV IgG antibodies were 19.1, 10.4 and 5.4\% in Kafr El-shiekh, El-Behera and

El Menoufia governorates, respectively.

Table 5: Detection of RVFV IgG antibodies among the examined human serum samples in relation to localities, Health status, Residence, Season and Sex by using ELISA test.

\begin{tabular}{|c|c|c|c|c|c|c|c|c|c|c|c|c|}
\hline & & \multicolumn{3}{|c|}{ localities } & \multicolumn{2}{|c|}{ Health status } & \multicolumn{2}{|c|}{ Residence } & \multicolumn{2}{|c|}{ Season } & \multicolumn{2}{|c|}{ Sex } \\
\hline & & Men. & Beh. & $\begin{array}{c}\text { Kafr } \\
\text { El }\end{array}$ & App.H & Febrile & Rural & Urban & $\begin{array}{c}\text { Warm } \\
\text { H. }\end{array}$ & $\begin{array}{c}\text { Cold. } \\
\text { H }\end{array}$ & Male & Female \\
\hline $\begin{array}{l}\text { Number } \\
\text { examined } \\
\text { samples }\end{array}$ & & 129 & 125 & 115 & 180 & 189 & 276 & 93 & 188 & 181 & 194 & 175 \\
\hline \multirow{2}{*}{$\begin{array}{l}\text { Sero- } \\
\text { positive }\end{array}$} & No & 7 & 13 & 22 & 16 & 26 & 35 & 7 & 23 & 19 & 25 & 17 \\
\hline & $\%$ & 5.4 & 10.4 & 19.1 & 8.9 & 13.8 & 12.7 & 7.5 & 12.2 & 10.5 & 12.9 & 9.7 \\
\hline
\end{tabular}

The detection percentages of RVF antibodies in febrile patients of unknown origin and apparently healthy persons were 13.7 and $8.8 \%$, respectively. Also, the detection percentages of RVF IgG antibodies among the examined human living in rural and urban areas were 12.6 and $7.5 \%$, respectively.

Table 6: Detection of RVFV IgG antibodies among the examined human serum samples in relation to Occupational status and Age groups by using ELISA test.

\begin{tabular}{|c|c|c|c|c|c|c|c|c|c|c|c|c|}
\hline & & \multicolumn{6}{|c|}{ Occupational status } & \multicolumn{5}{|c|}{ Age (years) } \\
\hline & & Sheepherder & Butchers & Farmers & $\begin{array}{l}\text { Lab. } \\
\text { and } \\
\text { vet }\end{array}$ & $\begin{array}{l}\text { House } \\
\text { wives }\end{array}$ & Others & $<15$ & $\begin{array}{l}15- \\
30\end{array}$ & $\begin{array}{l}30- \\
45\end{array}$ & $\begin{array}{l}45- \\
60\end{array}$ & $>60$ \\
\hline $\begin{array}{l}\text { Number of } \\
\text { samples }\end{array}$ & & 22 & 8 & 50 & 27 & 88 & 174 & 52 & 103 & 108 & 82 & 24 \\
\hline \multirow{2}{*}{$\begin{array}{l}\text { Sero- } \\
\text { positive }\end{array}$} & No & 7 & 1 & 10 & 3 & 11 & 11 & 3 & 12 & 18 & 7 & 2 \\
\hline & $\%$ & 31.8 & 12.5 & 20 & 11.1 & 12.5 & 6.3 & 5.8 & 11.7 & 16.7 & 8.5 & 8.3 \\
\hline
\end{tabular}

The detection percentages of RVFV IgG antibodies were $31.8,12.5,20,11.1,12.5$ and $6.3 \%$ in sheepherders, butchers, farmers, laboratories and veterinarians, house wives and other persons, respectively.

Table 7: Identification of collected mosquitoes according to genus in different localities.

\begin{tabular}{cccccc}
\hline & & Culex & Aedes & Anopheles & Total (pool) \\
\hline El-Menoufia & & 6 & 2 & 1 & 9 \\
\hline El-Behera & & 8 & 2 & - & 10 \\
\hline Kafr El -Sheikh & & 9 & 3 & 1 & 13 \\
\hline Total (pool) & No & 23 & 7 & 2 & 32 \\
\cline { 2 - 6 } & $\mathbf{\%}$ & 71.8 & 21 & 6.25 & \\
\hline
\end{tabular}


The percentages of collected mosquitoes were $71.8 \%$ ( 23 out of 32 ) for Cx. species, $21 \%$ ( 7 out of 32 ) for Aedes species, and $6.25 \%$ (2 out of 32 ) for Anopheles species.

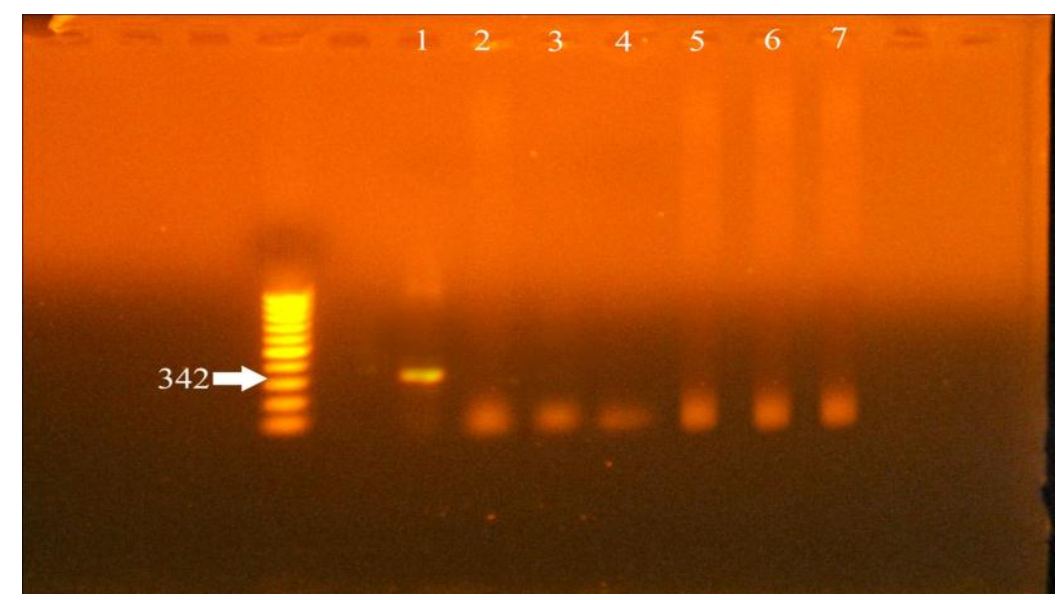

Figure (1): Gel electrophoresis stained with ethidium bromide indicating that all mosquito pools and inactivated vaccine did not show any band at the expected size ( $342 \mathrm{bp}$ ) by using specific primer for RVF virus.

MW: 100 bp DNA ladder

Lane 1: positive control (RVF virus)

Lane 2: Negative control

Lane 3: Negative result for inactivated vaccine of RVF virus

Lane 4,5,6,7: Negative mosquito samples

\section{DISCUSSION}

Rift Valley Fever is a classical anthropozoonosis where the disease is obligatory transmitted from the animal host to man, the disease has to appear first in animals before the clinical manifestions appear in human.

In this study the overall detection percentages of RVFV IgG antibodies in sheep, goats, cattle and buffalo were illustrated in table 2. The lower percentage of RVFV antibodies in vaccinated animals might be attributed to that the sero-positive RVFV IgG antibodies in non vaccinated animals, either recovered from infection or the disease still running in an unrecognized form among them, another possibility is the introduction of the live attenuated virus by mosquito bite from vaccinated to nonvaccinated animals. In addition, missed vaccination and the possibilities of animals escaping from vaccination campaigns which occurred every 6 months in Egypt (Kathrynt et al., 1991). On the other hand, it might be attributed to many factors as the immune response of each animal, healthy conditions, presence of stress factors, locality, time of sampling and mainly period of vaccination.Generally, vaccination of livestock in Africa has been expensive, leading to endemicity of RVF in most African countries (Balky and Memeish, 2003). The detection percentages of RVFV antibodies among non vaccinated animals were $(21.4,14.7$ and $8.6 \%$ in Kafr El-Shiekh, El Behera and El Menoufia Governorates, respectively (table 2). These results might be attributed to the nature of these rural governorates where extensive agriculture areas, irrigation canals and rice fields are considered as preferable habitates for mosquitoes, specially in Kafr El- sheikh than the other two governorates (Martine et al., 2008). Moreover, the suspected spreading of infection during 2003 outbreak in Kafr El-Shiekh (WHO, 2003 and Azzam et al., 2005).

Concerning, animal species, highest percentages RVFV IgG antibodies were recorded in sheep and goats than other animal species (table 1). This might be due to the breeding system of sheep and goats, which depend mainly on mobile flocks in opened grasses that lead to exposure to mosquito vector than other domestic animals as cattle where their breeding system mainly depend on closed farms with less exposure to mosquito bites (Youssef, 2004). In addition, the economic importance of cattle over sheep, which make the owner more keen to vaccinate and treat them. Furthermore, vaccination of sheep against RVF usually not occure regularily as a vaccination regim like in cattle and buffalo farms (Youssef, 2004; Maysa, 2006; Ramadan, 2009 and Kassem, 2011).

Some potential risk factors associated with detection of RVFV IgG antibodies in animals were studied. The results indicated that the RVFV IgG antibodies are more likely to be detected in old age animals than in younger ones (table 3). These finding might be 
attributed to that older animals are more likely to contract infection either by vaccination by strains of RVF or field strains cycling in the field either by mosquito bite or exposure to other source of infection (Youssef, 2004 and Maysa, 2006).

Owing to sex of the examined animals, females of sheep, cattle and buffaloes are more likely to carry RVFV IgG antibodies than males of these species (table 3). This result might be due to that lactating and breeding females are reared for older ages than males (Maysa, 2006). The higher overall detection percentages of RVF antibodies in previously aborted non vaccinated animals $(15.9 \%)$ reflect the direct relationship between abortion and RVF seropositivity especially sheep and goats (Formently et al., 1992). Regarding to the role of climatic conditions in occurrence of RVFV, data recorded in table 3 explained the slightly higher detection of RVF antibodies during warm humid season $(16.3 \%)$ than during cold humid season $(13.1 \%)$ in all investigated governorates. These results might be attributed to the prevalence of culex pipiens mosquitoes during warm season. Furthermore, in summer there is a maximum risk associated with the rice growing season, where high humidity and/or flooded rice fields coupled with warm temperature act as risk factors for RVFV activity (Martine et al., 2008).

Presence of the disease among animals impose a great risk of transmission to human contacts. The detection of RVFV IgG antibodies among the examined human serum samples was explained in table 4 . The results might be referred to the presence of extensive rice fields all over the three governorates, which are irrigated with high quantities of water. These rice fields and wet lands constitute an optimum habitat for breeding and maintenance of mosquitoes. This may explain the outbreak occurrence in 2003 in Kafr El sheikh and the highest detection of RVFV antibodies in human and animal serum (WHO, 2003 and Azzam et al., 2005).

Some potential risk factors associated with human infection (Health status, residence, season, sex, occupational status and age) were investigated table 5. These finding might be attributed to the epizootic nature of RVF in these governorates especially in rural areas where persons living in small villages with exposure to potentially infected livestock living near vegetation and irrigation canals that favor the breeding habitats of arthropode vectors and subsequently attracting RVF disease while sleeping outdoors (Seleem et al., 2002; Youssef, 2004 and Ramadan, 2009). Higher detection percentages of RVFV IgG antibodies were recorded in the serum of the examined patients during warm humid (12.2\%) than cold season (10.4\%) (table 5). The increased humidity due to irrigation of fields in the rural areas in addition to high temperatures enhance development and breeding of moaquito population. In addition, these hot humid conditions encourage many villagers for sleeping outdoors during the night which make them more exposed to mosquito bites and consequently increase the chance for infection (ElSharkawy and Sobhy, 1993). Moreover, the detection percentages of RVF IgG antibodies was higher in males $(12.8 \%)$ than females $(9.7 \%)$ as observed in table 5. This fact might be due to that males are at higher risk of infection than females due to the nature of their work in the fields and increasing chance of contact with infected animals or other infectious materials (Mostafa et al., 1996 and Naguib, 1999).

The occupation played an important role in infection with RVF, examination of human serum samples in the investigated localities confirmed this notion (table 6 ). The results might be attributed to that persons at high risk of infection with RVF due to their duties require continous contact with infected animals (Woods et al., 2002). The relationship between RVFV IgG antibodies and age of examined persons was also studied as that shown in table 6 as follow, $5.7 \%$ in the age group less than 15 years; $11.6 \%$ in the age group $15-30$ years; $16.6 \%$ in the age group $30-45$ years; $8.5 \%$ in the age group $45-60$ years and $8.3 \%$ in the age group $>60$ years by ELISA test. These results explained that the age group 30-45 y old was at the highest risk followed by the age group 15$30 \mathrm{y}$ old then the age group 45-60 y old and the age group $>60$ y old this might be attributed to the fact that these persons are incorporated in the occupational risk groups where subjects of these ages represent the working age that are closely associated with animals (Maysa, 2006), also might be due to the endemicity of Schistosoma amongst these age groups with increasing age and subsequently increased susceptibility to infection (Meegan et al., 1979).

Table (7) show identification and percentages of mosquito genera in different collected mosquito groups. It was found that Culex species constituted most of the collected mosquitoes in this study. This result was in agreement with many entomological studies carried out in Egypt to determine the role of mosquitoes in transmission of RVFV such as (Hoogstral et al., 1979 and Meegan et al., 1980).

The RT-PCR is often used as a supportive diagnostic assay to the time consuming and cumbersome conventional virus isolation laboratory procedure. The rapidity, sensitivity and specificity of the RTPCR assay would greatly facilitate detection of RVFV infection during an outbreak of the disease among humans and susceptible animals (Mohamed and Imadeldin, 2006).

Concerning to the occurrence of RVFV antigen in the collected mosquito pools by RT-PCR, figure (1) showed that the all examined mosquito groups and 
inactivated RVF vaccine did not show any band at the expected size (342bp). In addition only the positive control showed band at the expected size by using the specific primer to RVF virus. In the current study, the negative result did not indicate that RVFV was completely absent in mosquitoes in Egypt during the period of study; RVFV is often circulating at very low levels during inter-epizootic periods. Alternatively, the virus could indeed be absent in the area of sampling area, but may present in other areas this was supported by (Morvan et al., 1992). Also, surveillance system must be alert for any expecting outbreak from neighboring countries or flaring up infection during inter-epizootic period.

\section{REFERENCES}

Azzam, R.A.; Ibrahim, M.A. and Magda, M.S. (2005): Seroprevalence of Rift Valley fever, in sheep and humans, Seedy Salem (2003). Beni-Suef Vet. Med. J. 15(2): 284-88.

Balkhy, H.H. and Memish, Z.A. (2003): Rift Valley fever: an uninvited zoonosis in the Arabian Peninsula. International Journal of Antimicrobial, 21: 153-157.

Bird, B.H.; Bawiec, D.A.; Ksiazek, T.G.; Shoemaker, T.R. and Nichol, S.T. (2007): Highly sensitive and broadly reactive quantitative reverse transcriptase PCR assay for high throughput detection of Rift Valley Fever Virus. Journal of Clinical Microbiology, 45(11): 3506-513.

Bird, B.H.; Albarino, C.G.; Hartman, A.L.; Erickson, B.R.; Ksiazek, T.G. and Nichol, S.T. (2008): Rift Valley Fever virus lacking the NSs and NSm genes is highly attenuated, confers protective immunity from virulent virus challenge, and allows for differential identification of infected and vaccinated animals. J. Virol. 2008 Mar.; 82(6): 2681-91.

El-Sharkawy, S.A. and Sobhy, A.R. (1993): Highlights on some epidemiological points in Rift Valley fever outbreak in Aswan, Egypt. Report of the WHO/IZsTe consultation on recent development in Rift Valley fever (with the participation of FAO and OIE). Civitella del Tronto. Italy. 14-15

Formently, P.; Domenech, J. and Zeller, H.G. (1992): Serological survey of Rift Valley fever in sheep on the Ivory Coast. Rev. Elev. Med. Vet. Pays. Trop., 45(3-4):221-6. September 1993.

Gad, A.M.; Riad, I.B. and Farid, H.A. (1995): Host feeding pattern of Culex pipiens and $\mathrm{C}$. antennatus (Dipetera: Culicidae) from a village Sharqia governorate, Egypt. J. Med. Entomol., 32(5): 573-77.

Hoogstraal, H.; Meegan, J.M.; Khalil, G.M. and Adham, F.K. (1979): The Rift Valley fever epizootic in Egypt 1977-1978. 2. Ecological and entomological studies. Transactions of the Royal Society of Tropical Medicine and Hygiene, 73(6): 624-629.

Ikegami, T. and Makino, S. (2011): The Pathogenesis of Rift Valley Fever. Viruses 2011, 3, 493-519.

Kassem, H. (2011): Effect of Enviromental and Ecological factors on the Epidemiology of Rift valley Fever disease. M.V.Sc. thesis (master degree), Department of Animal, Poultry and Enviromental Hygiene, Faculty of Veterinary Medicine, Banha University.

Kathryn, A.H.; Bass Kerville, A. and Stephenson, J.R. (1991): Ability of amutagenized virus variant to protect young lambs from Rift Valley Fever. Amer. J. Vet. Res., 52(1): 50-55.

Martine, V.; Chevalier, V.; Ceccato, P.; Anyamba, A.; De Simone, L.; Lubroyh, J.; De La Rocque, S. and Domenech, J. (2008): The imoact of climate change on the epidemiology and control of Rift Valley Fever, Rev. Sci. Tech. Off. Int. Epizoot., 27 (2): 413-426.

Maysa, Awadallah, A.E. (2006): Some epidemiological studies on Rift Valley fever. Ph.D. Thesis (Zoonoses), Department of Zoonoses, Fac. Vet. Med., Zagazig University. Meegan, J.M.; Hoogstraal, H. and Moussa, M.I. (1979): An epizootic of Rift Valley fever in Egypt in 1977. Vet. Rec., 105: 124-125.

Meegan, J.M.; Khalil, G.M.; Hoogstraal, H. and Adham, F.K. (1980): Experimental transmission and field isolation studies implicating Culex pipiens as a vector of Rift Valley fever virus in Egypt. American Journal of Tropical Medicine and Hygiene, 29(6): 1405-1410.

Mohamed, A.E. and Imadeldin, E.A. (2006): A simple and rapid method for detection of Rift Valley Fever Virus in cell culture using RT-PCR. International Journal of Tropical Medicine, 1(1): 44-47.

Morvan, J.; Rollin, P.E.; Laventure, S.; Rakotoarivony, I. and Roux, J. (1992): Rift Valley fever epizootic in the central highlands of Madagascar. Res Virol., 143(6): 407-15.

Mostafa, O.; Reda, W.W.; Bahgat, M. and Siam, M. (1996): Clinical and serological studies on human Rift Valley fever during sheep epizootic. Med. J. Cairo Univ., 64(4): 975-81.

Naguib, M.S. (1999): Sero-epidemiological studies on Rift Valley fever in some patients of fever hospital in Upper Egypt. M.V.Sc in Zoonoses, Faculty of Veterinary Medicine, Assuit University, Egypt.

NAMRU-3 (1998): Rift Valley Fever human IgG $(\gamma$ chain) ELISA Sop-SER- 101.

Paweska, J.T.; Burt, F. and Swanepoel, R. (2005): Validation of enzyme-linked immunosorbent assay for the detection of $\mathrm{IgG}$ and $\operatorname{IgM}$ 
antibody to Rift Valley fever virus in humans. Journal of Virological Methods, 124: 173-181.

Ramadan, H. (2009): An epidemiological study on RVF as a zoonotic viral disease transimitted by arthropods and its public health importance. M.V.Sc. thesis (master degree), Department of Animal Hygiene and Zoonoses, Faculty of Veterinary Medicine, Mansoura University.

Salim, R.W.; Khiralla, M.S.; Eljamal, A.A.; Karrar, A.E. and Aradiab, I.E. (2010): A single- Tube RT- PCR Amplification for Detection of Rift Valley Fever virus.

Seleem, M.N.; Asmaa, A.A. Hussein; Ismail, A.A. and Nafie, E.K. (2002): Serological studies on RVF in some patients of fever hospital in Upper Egypt. J. Egypt. Vet. Med. Assoc., 62(6a): 261-71.

Swaneopel, R. and Coetzer, J.A.W. (1994): Rift Valley fever. In Infectious Diseases of livestock with special reference to Southern Africa. (ed. Coetzer, J.A.W.; Thomson, G.R. and Tustin, R.C.). 663-70. Oxford University Press Southern Africa, Cape Town.

WHO (2003): Rift Valley fever, Egypt. Weekly Epidemiological Record (WER), 78(36): 313-320.
Woods, C.W.; Karpati, A.M.; Grein, T.; McCarthy, N.; Gaturuku, P.; Muchiri, E.; Dunster, L.; Henderson, A.; Khan, A.S.; Swanepoel, R.; Bonmarin, I.; Martin, L.; Mann, P.; Smoak, B.L.; Ryan, M.; Ksiazek, T.G.; Arthur, R.R.; Ndikuyeze, A.; Agat, N.N.; Peters, C.J. and the World Health Organization Hemorrhagic Fever Task Force. (2002): An outbreak of Rift Valley fever in Northern Kenya, 1997-98. Emerging Infectious Diseases, 8(2): 138-144.

Youssef, B.Z. (2001): Application of reverse transcriptase-polymerase chain reaction for detection of Rift Valley Fever viral antigen from mosquito. J. Egypt Public Health Assoc., 76(3-4): 297-308.

Youssef, A.I. (2004): An epidemiological study on RVF in Ismailia Province. M.V.Sc. thesis (master degree), Department of Animal Hygiene, Behavior and Zoonoses, Faculty of Veterinary Medicine, Suez Canal University.

Youssef, H.M.; Ghoneim, M.A.; Degheidy, N.S.; Habeeb, S.M. and Said, A.F.A. (2008): Recent trends for diagnosis of Rift Valley Fever in animals and mosquitoes in Egypt with special reference to the carrier. Global Veterinaria, 2(1): 01-06.

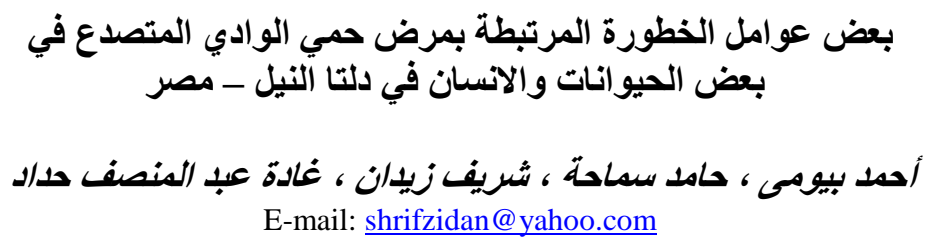

حمي الوادي المتصدع هو مرض فيروسي مثنترك بين الانسان والحيوان يصيب كثيرا من الحيوانات المجترة و الجمال وكذ للك الإن

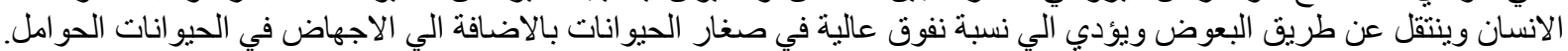

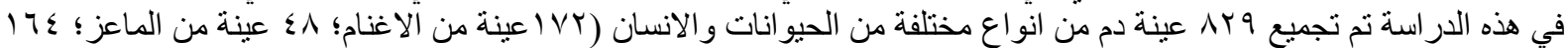

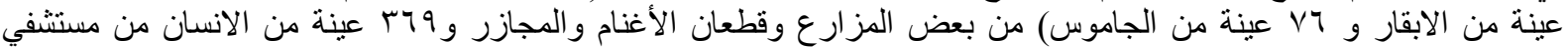

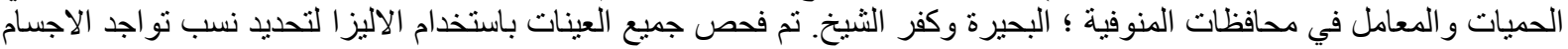

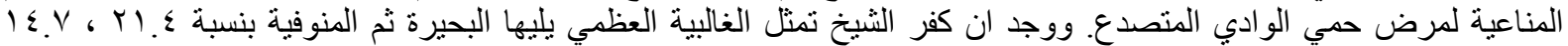

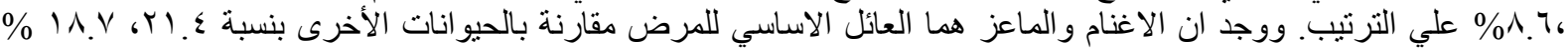

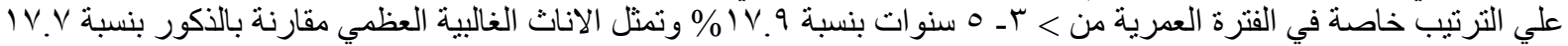

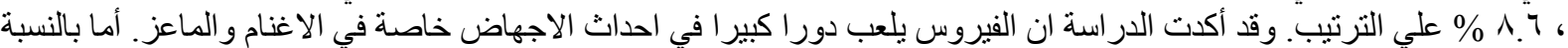

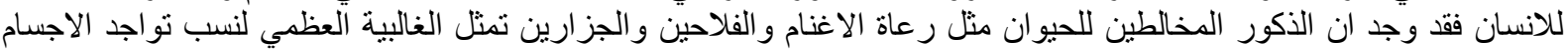

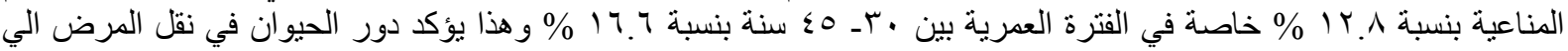

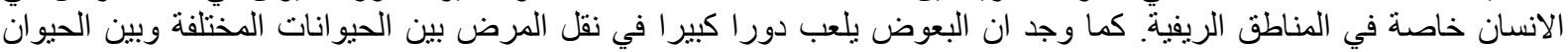

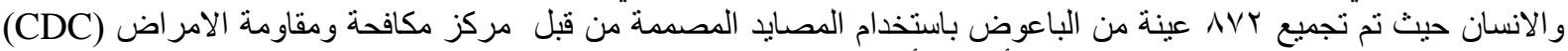

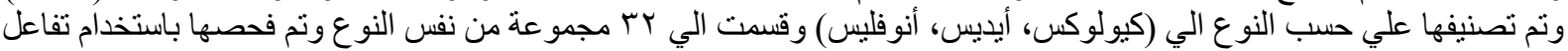

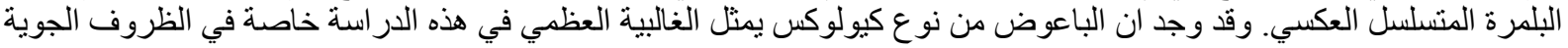

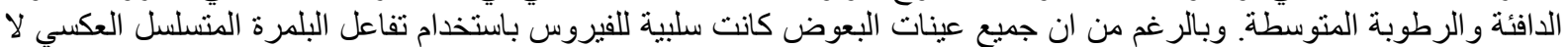
يعني هذا غياب الفيروس تماما لأنه احتمال وجوده بمن بمعدل قليل في المنطقة موضع الدراسة أو وجوده في محافظات أخري في مصر. 